
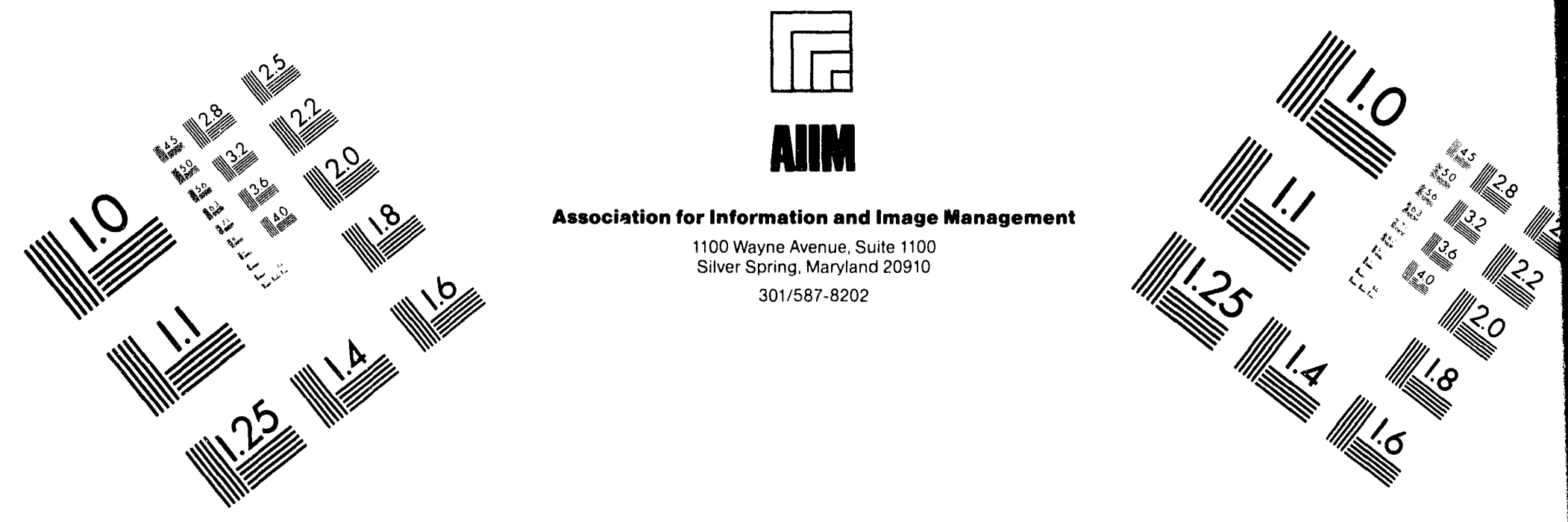

\title{
Centimeter
}

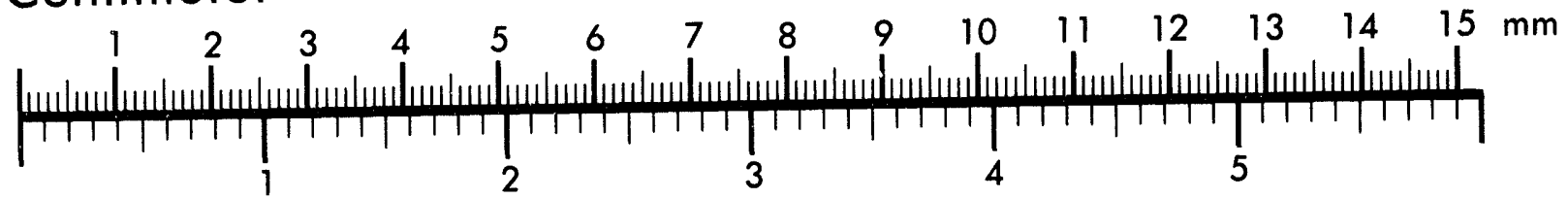

Inches
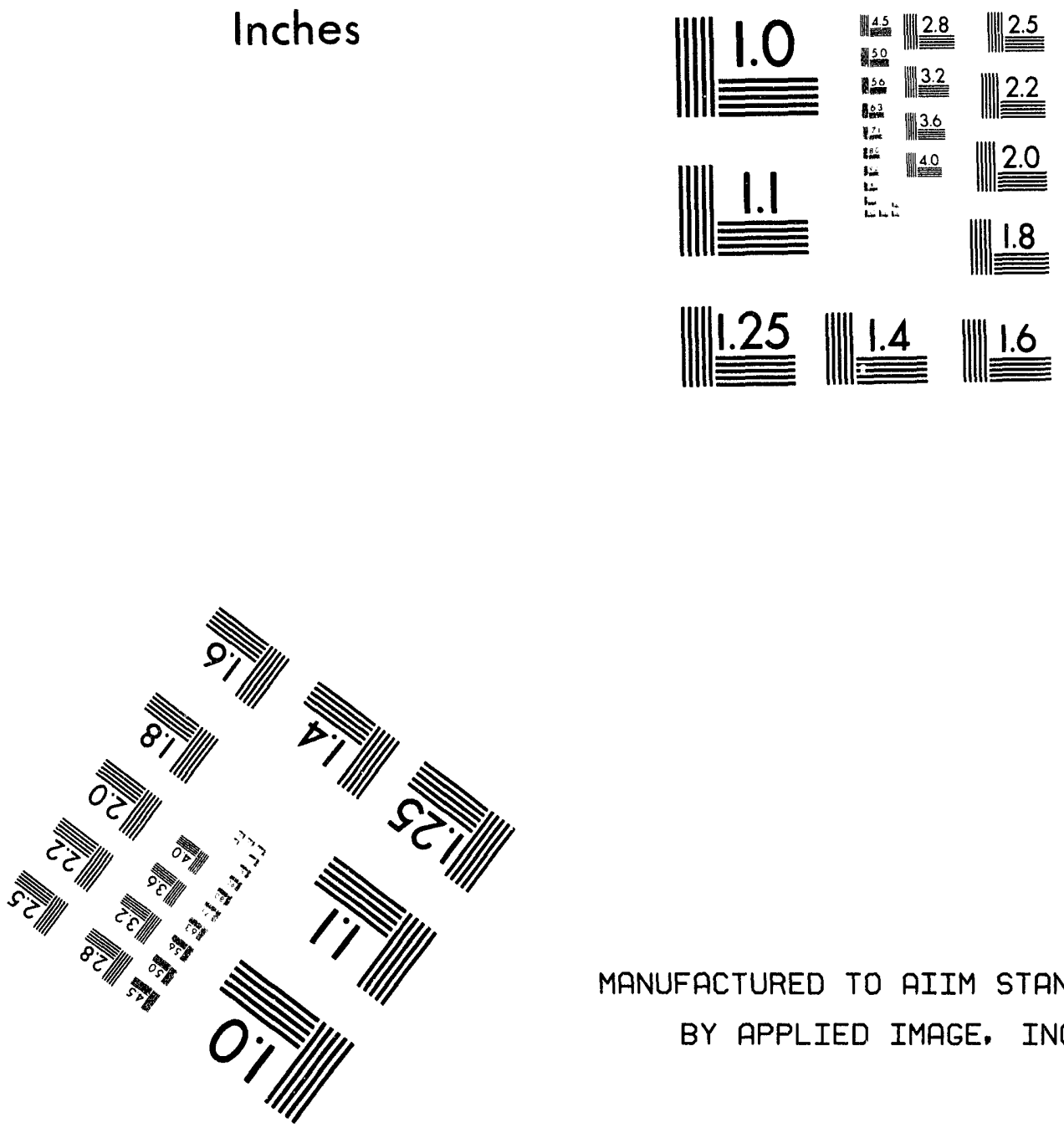

MANUFACTURED TO AIIM STANDARDS

BY APPLIED IMAGE, INC.

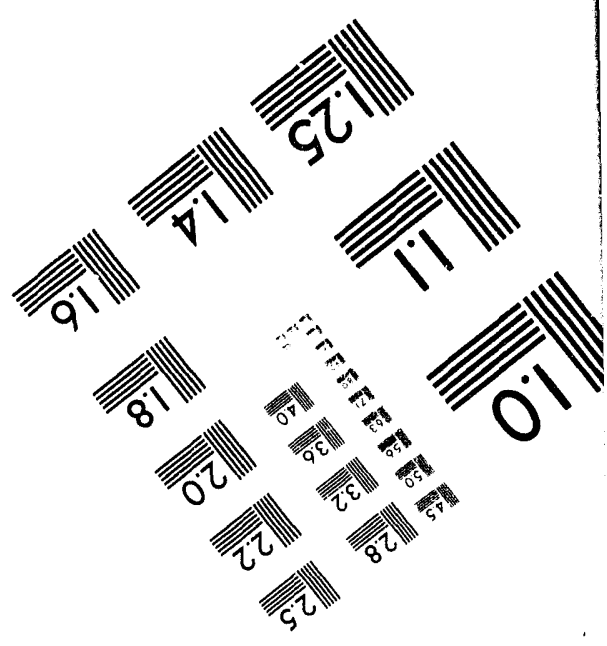



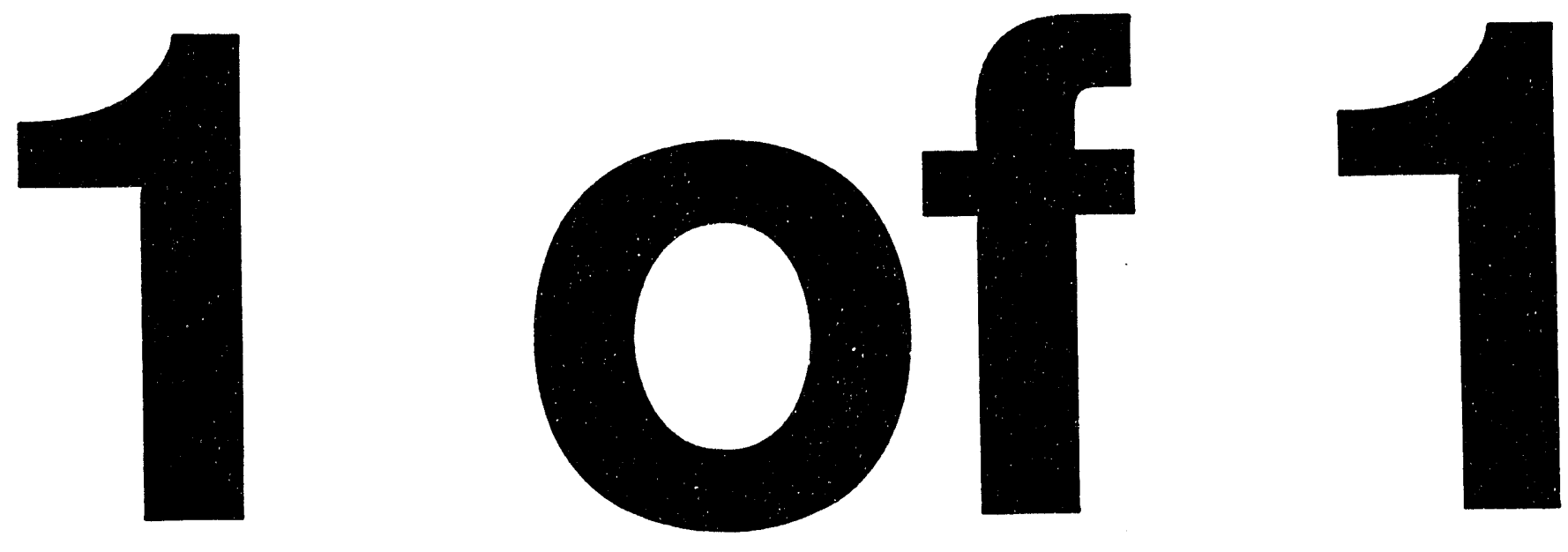
E.I.du Pont de Nemours \& Co. Explosives Department Atomic Energy DIvision Wilnington, Delaware

\section{Claselficay on Cancollodremanand}

TO

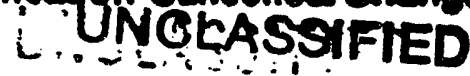

By Authority of

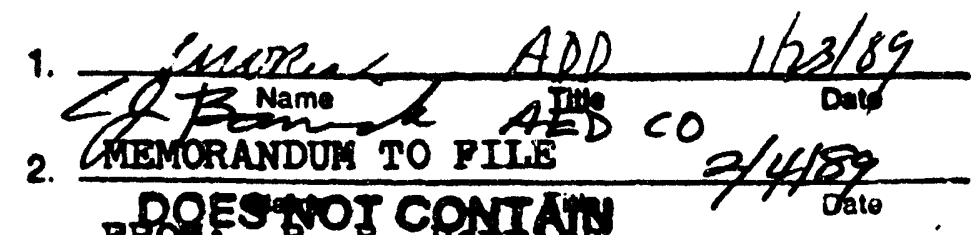
POES TOT COATIS UNCLASSIFED COWHALLED NUCLEAR INFORMATION Buinuin envis.<smiles>[R]C1=CC=C1</smiles>

Tr1p Report

BATTELLE MEMORIAL INSTITU

January 25-26, 1955

13 - George Tuer

14 - TIS File

Pebruary 3, 1955

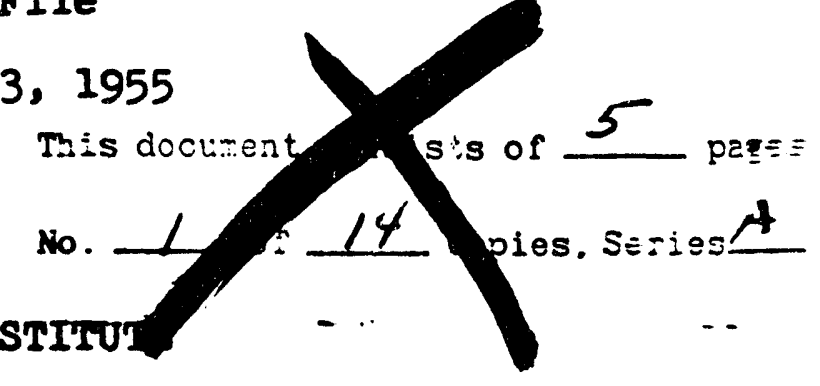

Dato

W. J. O'Leary and R. R. Herries visited BMI to review the progress

or sutoon on extended surface fuel elements and on

the consolidation of thorlum powder.

gordunary

1. Seven electrodes of Horlzons' powder have been pressed and satisfactorily arc melted under various conditions.

2. A second lot of 18 to 20 lbs. of Horlzons' metal has been recelved at BMI for melting.

3. Elghteen of the proposed 33 "half-dollar" uranlum corrosion samples for linvestigation of higher bonding pressures have been prepared. Ten of these are on test in boling dist1lled water.

4. Three ERI Pluld-pressure-bonded uranlum corrosion samples falled due to sheath rupture after 31-33 days on test; no "undercutting" was evident. These samples have shown satisfactory corrosion resistance.

\section{DISCUSSION}

A. Uranium

1. Mechanical Hot Die Pressing

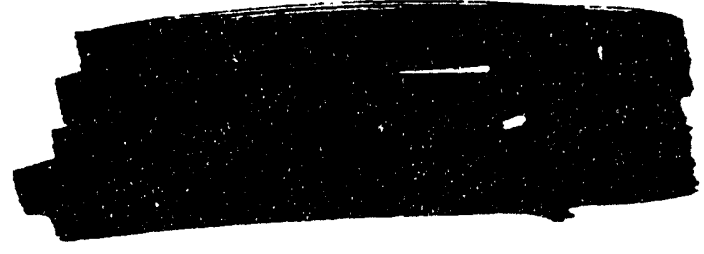

"Half-dollar" size uranium corrosion samples for the $\cdot x^{2}+4$ purpose of evaluating the effects of higher bonding pressures are being press-clad w1th 30-m1l aluminum at BMI. 
Specimens of nickel-plated uranium, I" in diameter $x$

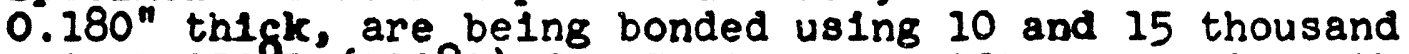
p81 at $950^{\circ}\left(510^{\circ} \mathrm{C}\right)$ for 5 minutes. After pressing, the assemblies are plnch-welded around the edges of the a luminum sheath and are "plnholed" with a 15-mil hole. Samples bonded similarly at 6000 ps 1 are belng corrosion tested in bolling distilied water to serve as a basis for comparing the behavior of the samples prepared under the higher pressures when tested under the same conditions.

2. Electroplating of Nickel on Uranium

In conjunction with the press-cladding of uranium, a discussion of electroplating nickel on uranium was held with BMI personnel.

Since uranium cleaning and electroplating techniques may greatly affect the quality and corrosion resistance of uranium-nickel-aluminum bonded systems, it is necessary that those procedures used for the preparation of test specimens be standardized with the procedures in use by the operating groups. For this reason, the BMI and SRI cleaning and nickel electroplating procedures were discussed and compared.

In earlier work on press-clidding of nickel-plated uranium, bond strengths of hot pressed specimens were folind to be Inconsistent. This was attributed in part to poor adherence of the nickel plate. Consequently, it was thought desirable to roughen the uranium surface to provide better mechanical adherence of the nickel electroplate. Thts was accomplished in part by sandblasting at BMI; subsequent mild anodic treatment at BMI dId not appreclably Increase the surface roughness of the core. Since the SRI procedure uses hot nitric acid instead of sandblasting to remove oxide scale, It was considered at SRI that a more severe anodic treatment was required to produce a surface of approximately the same degree of roughness as that achleved with the BMI method. This more severe plcke, however, results in a correspondingly heavier oxide layer to be removed from the hills and valleys of the core surface. The nitric acid plckle ( $8,60-70^{\circ} \mathrm{C}$ for $30-40 \mathrm{sec}$ ) must completely remove this oxide to insure proper nickel-plating. Therefore, it is necessary that this step be closely controlled and standardized.

It was further agreed that the present pressing techniques warrant a review of the uranium surface roughness now necessary to achleve strong, corrosion-resistant bonds. If urantum-nickel-aluminum bonds of high strength can be attained with much smoother uranium surfaces, several advantages would be realized, $1 . e .$. (I) more continuous bonds, (2) easier cleaning. (3) easier electroplating of nickel. Items (1) and (2) above would be espec1ally beneficial to increase the resistance of press-clad fuel elements to undercutting corrosion.

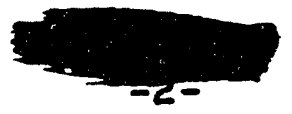


3. Extrusion Cladding

Due to lack of funds, no further work has been done on thls program during the last two weeks. A BMI report covering the work to date 18 being prepared showing that with the present die and mandrel tip, an extrusion cladding $5 / 32^{\prime \prime}$ thlck can be made. Past work was discussed, as well as tentative designs of equipment for extrusion cladding of plates by the porthole technique which is being proposed as an extension of the present program.

4. Corrosion

The three ERL fluld pressure bonded samples were removed from test after 744 to 792 hours ( 31 to 33 days). The se $1^{\prime \prime} \times 8^{n} \times 0.180^{\circ}$ nickel-plated uranlum cores, clad with 30-mil aluminum, had been drilled with a 15-mil pinhole and placed in bolilng distilled water. Plmples which appeared at the pinholes after 9 to 11 days grew in diameter unt1l they had proceeded over the edges of the $1^{\prime \prime}$ wide samples and ruptured the aluminum sheaths. The fact that no undercutting corrosion occurred was attributed to the continuous bond obtained with the uniform pressure ( $5000 \mathrm{psi}$ ) exerted by th1s method of presscladding, and to the benefits of degassing or dewatering the assemblies before pressing.

Corrosion test results from twelve $3^{\prime \prime} \times 5^{\prime \prime} \times 0.180^{\prime \prime}$ aluminum-clad uranium samples, coated with nickel by vapor decomposition of nickel carbonyl at the Mound Laboratory. pere inconclusive. As previousiy reported (DPU-55-24-1). the 4 to 5 weeks ' delay between nickel-coating and presscladding resulted in several non-bonded areas as weil as in areas of questionable bond. On corrosion testing, all but one specimen falled by undercutting after 2 to 14 days.

The group of 10 "half-dollar" samples, press-clad at 6000 psi as controls for the "high bonding pressure" samples. have been in boliling distilied water for 144 hours with one rallure. This sample undercut from the edge at $a$ = defective pinch-weld. Th1s group of samples will evaluate the theory that press-cladding at a higher average pressure than has previous Iy been standard w111 approximate the more uniform pressure obtained by fluid pressure bonding.

One as-pressed sample from each pressure range w11l be sectloned for metallography.

B. Thorium

1. Consolidation of Thorlum

Seven electrodes, compacted from Horlzons' metal, have been arc melted by BMI as their first attempt to consolidate and purify the powdery cathode material. Five of the $2^{n} \times 1^{n} \times 6^{n}$ thorlum electrodes, cold pressed at 50 tsi, had 
been sintered for e1ther $15 \mathrm{cr} 90$ minutes at $1250^{\circ} \mathrm{C}$ for melting, although the two initial melts were made with unsintered (green) electrodes. The conditions for each melt varied, as shown in the following data:

MeIt Number

Electrode

Green

Green

Sintered

Sintered

Sintered

$\left\{\begin{array}{l}90 \min \cdot-1250^{\circ} \mathrm{C} \\ 15 \min .-1250^{\circ} \mathrm{C}\end{array}\right\}$

Sintered

Sintered

$\left(\begin{array}{ccc}90 & \min .-1250^{\circ} \mathrm{C} \\ 15 & \min ^{\prime \prime} \cdot-1250^{\circ} \mathrm{C}\end{array}\right)$

Atmosphere
Less than 100 microns
20 inches He
20 inches He
20 inches He
Less than 100 microns
Less than 100 microns
20 inches He

Crucible S1ze

4"

4"

4"

4"

$4^{\prime \prime}$

$4^{\prime \prime}$

$2 \frac{1}{2} 1$

Considerable "splattering" occurred during each melt although the arc was falrly stable even at the lower

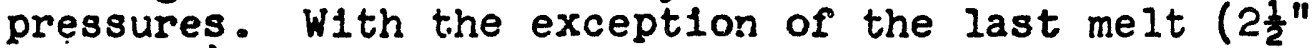
cruclble), the resulting ingots were coarsely spongy w1th more or less adhering globules. Very little difference was noted between melts from green or from sintered electrodes, although more splatter was experlenced from both types of melt at the lower pressures. Melt No. 7, using the $2 \frac{1}{2} "$ crucible, appeared falriy sound since the smaller diameter resulted in more heat input into the metal. Very little non-metalif sublimate was found in the furnace following the melts.

The minus 250-mesh material, which amounted to 4-5\% of the total as-recelved metal, had been removed by 40 minutes of screening in order to determ: ne the effects of fines on the oxide content of the melts. A screen analysis of the remalning metal showed a normal distribution of particle sizes. Taree chemical analyses made on the powder prior to compacting gave a carbon content of $0.03 \%$, and $\mathrm{HCl}$ insoluble values of $0.88,0.89$, and $0.75 \%$. Vacuum fusion results have not yet been recelved. Analyses of an unknown grey deposit found in the vacuum sintering furnace are also being made.

A shipment of 18 to 20 pounds of Fernald thorlum has been recelved at $B M I$.

2. Diffusion of Thorium into Aluminum

Diffusion couples of aluminum (99.99\%) and of an aluminum alloy containing $0.5 \%$ thorlum have been prepared for determining the amount of diffusion of thorium into aluminum that takes place beyond the limit which can be

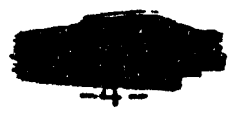


detected by metallographs. Two couples, bonded at $1125^{\circ} \mathbf{P}$ $\left(607^{\circ} \mathrm{C}\right)$ under a pressure of $6000 \mathrm{ps} 1$, were sectioned and found to be well bonded. Since a $1^{\prime \prime}$ aluminum cylinder is placed between two alioy cylinders, each sample will provide an extra couple for metallography or for a recheck. Annealing will be carried out at temperatures of $600^{\circ} \mathrm{C}$ and lower, to that lowest temperature at which measurable diffusion takes place within one month's time. Chemical analyses 111 be made on $2-\mathrm{ml} I$ cuts through the interface, and on 5 and $10-\mathrm{m} 11$ cuts farther from the interface, in order to determine the amount of diffusion that occurs through solid solution.

\section{DISCLAIMER}

This report was prepared as an account of work sponsored by an agency of the United States Government. Neither the United States Government nor any agency thereof, nor any of their employees, makes any warranty, express or implied, or assumes any legal liability or responsibility for the accuracy, completeness, or usefulness of any information, apparatus, product, or process disclosed, or represents that its use would not infringe privately owned rights. Reference herein to any specific commercial product, process, or service by trade name, trademark, manufacturer, or otherwise does not necessarily constitute or imply its endorsement, recommendation, or favoring by the United States Government or any agency thereof. The views and opinions of authors expressed herein do not necessarily state or reflect those of the United States Government or any agency thereof. 

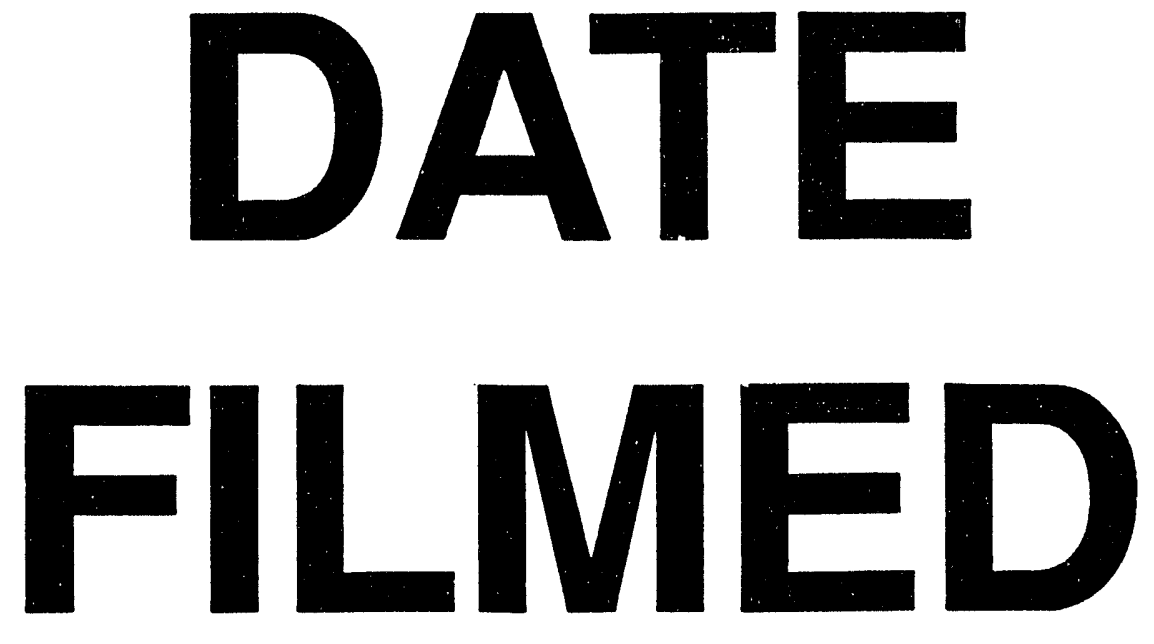

$10 / 20 / 94$
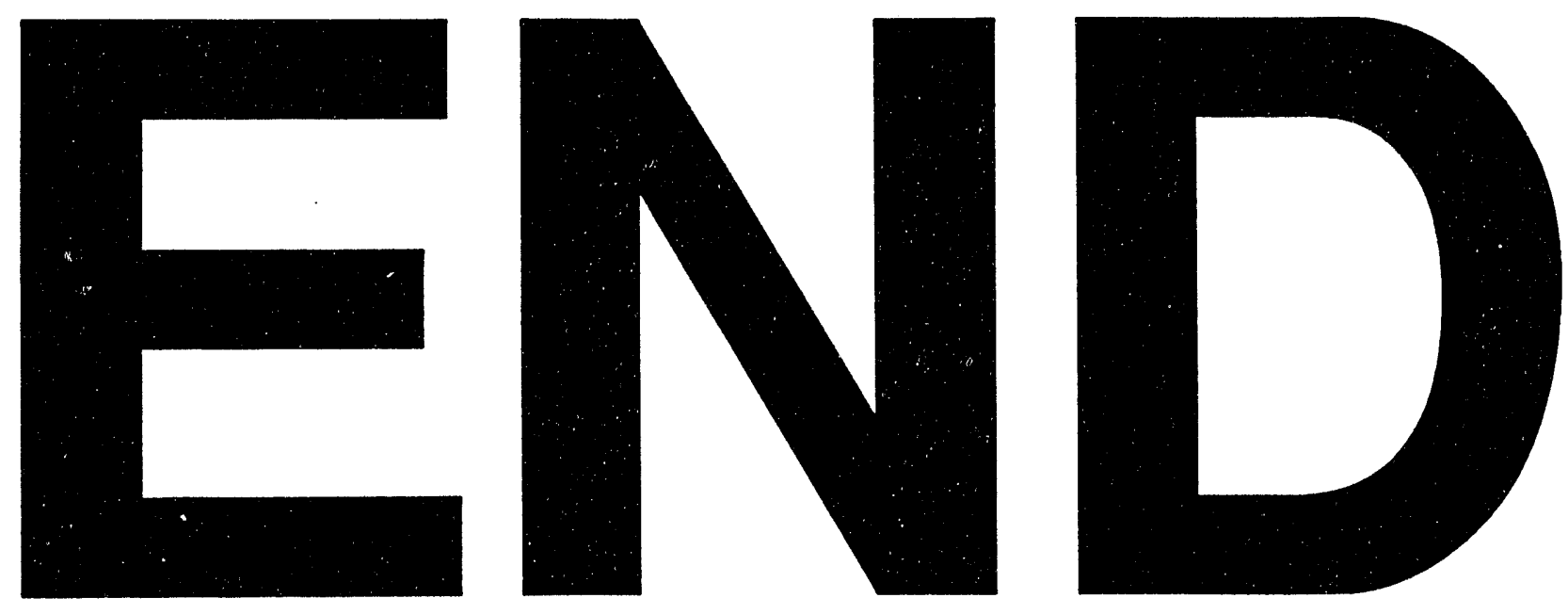
